(2) Open Access Full Text Article

ORIGINALRESEARCH

\title{
Impact of Therapy \& Age in Choroidal Cancers: A Retrospective Cohort Analysis of 7722 Patients from a US National Database
}

\section{Zain Hussain (D) \\ Jawad Khan \\ Shaheer Ali}

Paul L. Foster School of Medicine, Texas Tech University Health Sciences Center, El Paso, TX, USA
Correspondence: Zain Hussain Paul L. Foster School of Medicine, Texas Tech University Health Sciences Center, 500 I El Paso Dr., El Paso, TX, 79905, USA Email zain.hussain@ttuhsc.edu
Background: Collectively, choroidal cancers represent a vast array of histopathologically diverse constituencies with profound repercussions related to mortality and metastasis. Prognosticated factors provide utility in determining clinical management and outcome propensities. To date, measures to collectively characterize choroidal cancers as a class are not impressive. This study aims to shed light on the affiliation of age and therapeutic modalities to survival in patients diagnosed with choroidal cancers.

Methods: Cohort analysis using the Surveillance, Epidemiology, and End Results (SEER) program, a freely accessible population-based database, was executed from 1975 to 2016 , a 41-year time window. Univariable and multivariable Cox regression assessed survival with age and various therapeutic modalities as primary independent variables. Adjustment for several demographical and clinical variables was performed.

Results: This cohort consisted of 7722 patients at the time of diagnosis. Multivariable Cox regression demonstrated increased cause-specific hazards of $71.8 \%$ for patients aged $75+$ years $(\mathrm{HR}=1.718$, CI $1.155-2.555, \mathrm{p}<0.008)$ as compared to patients aged $0-24$ years. $16.2 \%$ and $58.0 \%$ increases in cause-specific mortality were showcased in patients diagnosed with 8770/3: mixed epithelioid and spindle cell melanoma $(H R=1.16, p=0.029)$ and 8771/3: epithelioid cell melanoma of the choroid $(H R=1.580, p<0.001)$ compared to individuals diagnosed with $8720 / 3$ : malignant melanoma NOS of the choroid. Chemotherapy significantly influenced survival in patients with choroidal cancers compared to those who did not receive chemotherapy or had an unknown status (HR $=0.377$, CI 0.292-0.486, $\mathrm{p}<0.001)$.

Conclusion: Like most cancers, choroidal cancers showcase poor clinical trajectory with advanced age. Specific ICD-O-3 histological subtypes predispose to increased mortality. Therapeutic modalities such as radioactive implants and chemotherapeutic agents demonstrate decreased cause-specific mortality compared to alternative treatments. Altogether, nuanced influences of age and therapy are revealed when evaluating choroidal cancers as a class, irrespective of subtype.

Keywords: choroid, cancer, survival, mortality

\section{Introduction}

Choroidal cancers arise in part due to the high vascular supply via the provision of the anterior and posterior ciliary arteries. ${ }^{1,2,6,7}$ Collectively, they supply oxygen and nutrients to the retina and surrounding structures. ${ }^{2,6,7}$ Interestingly, the choroid is well characterized as the recipient for the highest rate of vascular flow per unit weight compared to any other body tissue. ${ }^{4,6}$ In addition, the choroid is associated with the highest frequency of ocular metastatic disease, notably breast (40-47\%) and lung cancers (21-29\%). ${ }^{4,6}$ 
Treatment options for choroidal cancers include observation, chemotherapy, immunotherapy, radiotherapy, enucleation, and more. ${ }^{1-7}$ The appropriate treatment modality is dependent on various factors including age, laterality, localization, and systemic status of the patient. ${ }^{1-7}$ Regardless, prompt initiation of treatment for choroidal cancers should be implemented to secure the preservation of the patient's health.,

At the present moment, little to no research evaluates the collectivity of known choroidal cancers with respect to survival. Previous studies in patients diagnosed specifically with choroidal melanomas showcase associative increases in mortality, basal tumor diameter, metastatic capability with dissemination to the ciliary body and extraocular areas, with the progression of age..$^{5-8}$ Interestingly, a multitude of studies showcase a controversial association of survival with age in patients with uveal melanoma. ${ }^{9-12}$ An observational case series of 59 patients with choroidal lymphomas, a true rarity of the intraocular cancers, did not communicate a prognostication of survival by age. ${ }^{7}$ While these studies remark on survival in a specific type or subset of choroidal cancer, the authors' claim that this is one of the few studies attempting to characterize survival by age and therapy for choroidal cancers as a comprehensive denomination.

We hereby present a retrospective cohort study utilizing the Surveillance, Epidemiology, and End Results Program (SEER) to characterize the impact of age on survival in patients with choroidal cancers with adjustment for sex, race/ethnicity, marital status, Hispanic/NonHispanic origin, laterality, grade, ICD-O-3 Hist/behav, diagnostic confirmation, chemotherapy, radiation, radiation sequence, and type of follow-up expected.

\section{Methods}

The Surveillance, Epidemiology, and End Results (SEER) Program is a freely available, publicly accessible US national database comprised of patient de-identified population-based registries related to cancer-afflicted patients that are backed by the National Cancer Institute (NCI) and Centers for Disease Control and Prevention (CDC). This retrospective cohort analysis searched over 10 million patients within the "Incidence - SEER 18 Regs Custom Data (with additional treatment fields), Nov 2018 Sub (1975-2016 varying)" for patients diagnosed with choroidal cancers within a 41-year time window. Site and morphology for choroidal cancer patients was selected via the "Site recode ICD-O-3/WHO 2008" variable in search for
"C69.3-Choroid" as the primary labeled site. Inclusivity of all choroidal cancers yielded 9091 cases, including 8000/3: Neoplasm, malignant, 8010/3: Carcinoma, NOS, 8070/3: Squamous cell carcinoma, NOS, 8720/3: Malignant melanoma, NOS, 8721/3: Nodular melanoma, 8722/3: Balloon cell melanoma, 8723/3: Malignant melanoma, regressing, 8730/3: Amelanotic melanoma, 8740/3: Malignant melanoma in junctional nevus, 8743/3: Superficial spreading melanoma, 8745/3: Desmoplastic melanoma, malignant, 8761/3: Malignant melanoma in giant pigmented nevus, 8770/3: Mixed epithelioid and spindle cell melanoma, 8771/3: Epithelioid cell melanoma, 8772/3: Spindle cell melanoma, NOS, 8773/3: Spindle cell melanoma, type A, 8774/3: Spindle cell melanoma, type B, 8801/3: Spindle cell sarcoma, 9120/3: Hemangiosarcoma, 9590/3: Malignant lymphoma, NOS, 9591/3: Non-Hodgkin lymphoma, NOS, 9675/3: Malig lymphoma, mixed small and large cell, diffuse (OBS 2010+) see 9690/3, 9680/3: Diffuse large B-cell lymphoma (DLBCL), NOS, and 9699/3: Extranodal marginal zone lymphoma of mucosalassoc. lymphoid tissue-MALT. Age was stratified into 4 brackets of "0-24 years", "25-49 years", "50-74 years", and " $75+$ years".

To properly diagnose the relationship between age and survival in patients with choroidal cancers, multivariable analysis was performed with adjustment for sex, race/ ethnicity, marital status, Hispanic/Non-Hispanic origin, laterality, grade, ICD-O-3 Hist/behav, diagnostic confirmation, chemotherapy, radiation, radiation sequence, and type of follow-up expected. In addition, various treatment modalities including chemotherapy and radiation therapy were independently assessed for impact on survival in those with choroidal cancers.

Statistical significance was defined as a $p$-value $\leq 0.05$. All analyses were performed in IBM SPSS Version 26.

\section{Results}

Table 1 shows the descriptive statistics of the $\mathrm{N}=7722$ patients with a valid cause of death classification. Note that nearly all patients had malignant $(99.9 \%)$ choroidal cancer and active follow-up (99.9\%) was expected.

Cohort stratified by age showcases 4698 patients (60.8\%) aged 50-74 years, 1576 (20.4\%) aged 25-49 years, $1353(17.5 \%)$ aged $75+$ years, and $95(1.2 \%)$ aged 0-24 years at the time of diagnosis. 4104 (53.1\%) patients and $3618(46.9 \%)$ patients were male and female, respectively. Upon diagnosis, $99.9 \%$ of patients pursued active follow-up with 2 cases $(<0.1 \%)$ considered autopsy/death 
Table I Baseline Demographical \& Clinical Characteristics

\begin{tabular}{|c|c|c|c|c|}
\hline Variable & Value & Frequency & Percent & $p$-value \\
\hline Age (years) & $\begin{array}{l}0-24 \\
25-49 \\
50-74 \\
75+\end{array}$ & $\begin{array}{l}95 \\
1576 \\
4698 \\
1353\end{array}$ & $\begin{array}{l}1.2 \\
20.4 \\
60.8 \\
17.5\end{array}$ & $p<0.001$ \\
\hline Sex & $\begin{array}{l}\text { Male } \\
\text { Female }\end{array}$ & $\begin{array}{l}4104 \\
3618\end{array}$ & $\begin{array}{l}53.1 \\
46.9\end{array}$ & $p=0.146$ \\
\hline Marital Status & $\begin{array}{l}\text { Married } \\
\text { Single } \\
\text { Widowed } \\
\text { Divorced } \\
\text { Other/Unknown }\end{array}$ & $\begin{array}{l}4772 \\
958 \\
818 \\
551 \\
623\end{array}$ & $\begin{array}{l}61.8 \\
12.4 \\
10.6 \\
7.1 \\
8.1\end{array}$ & $p=0.002$ \\
\hline Race/ethnicity & $\begin{array}{l}\text { White } \\
\text { Non-white }\end{array}$ & $\begin{array}{l}7462 \\
260\end{array}$ & $\begin{array}{l}96.6 \\
3.4\end{array}$ & $\mathrm{P}<0.001$ \\
\hline Hispanic Origin & $\begin{array}{l}\text { Spanish-Hispanic-Latino } \\
\text { Non-Spanish-Hispanic-Latino }\end{array}$ & $\begin{array}{l}376 \\
7346\end{array}$ & $\begin{array}{l}4.9 \\
95.1\end{array}$ & $P=0.008$ \\
\hline Laterality Recode & $\begin{array}{l}\text { Left } \\
\text { Right } \\
\text { Other/Unknown }\end{array}$ & $\begin{array}{l}3842 \\
3811 \\
69\end{array}$ & $\begin{array}{l}49.8 \\
49.4 \\
0.9\end{array}$ & $P=0.393$ \\
\hline Grade & $\begin{array}{l}\text { Well-differentiated; Grade I } \\
\text { Moderately differentiated; Grade II } \\
\text { Poorly differentiated; Grade III } \\
\text { Undifferentiated; anaplastic } \\
\text { Grade IV and B-cell; pre-B; B-precursor }\end{array}$ & $\begin{array}{l}60 \\
7512 \\
94 \\
34 \\
22\end{array}$ & $\begin{array}{l}0.8 \\
97.3 \\
1.2 \\
0.4 \\
0.3\end{array}$ & $P=0.42$ \\
\hline ICD-10-Behavior & $\begin{array}{l}\text { 8720/3: Malignant melanoma, NOS } \\
\text { 8770/3: Mixed epithelioid and spindle cell melanoma } \\
\text { 8774/3: Spindle cell melanoma, type B } \\
\text { 8772/3: Spindle cell melanoma, NOS } \\
\text { 8771/3: Epithelioid cell melanoma } \\
\text { 8730/3: Amelanotic melanoma } \\
\text { 8773/3: Spindle cell melanoma, Type A } \\
\text { Other/Unknown }\end{array}$ & $\begin{array}{l}5610 \\
780 \\
477 \\
467 \\
261 \\
58 \\
20 \\
49\end{array}$ & $\begin{array}{l}72.6 \\
10.1 \\
6.2 \\
6 \\
3.4 \\
0.8 \\
0.3 \\
0.6\end{array}$ & $\mathrm{P}<0.001$ \\
\hline Diagnostic confirmation & $\begin{array}{l}\text { Positive histology } \\
\text { Radiography without microscopic confirmation } \\
\text { Direct visualization without microscopic confirmation } \\
\text { Positive exfoliative cytology, no positive histology } \\
\text { Clinical diagnosis only } \\
\text { Other/Unknown }\end{array}$ & $\begin{array}{l}3993 \\
1423 \\
1184 \\
512 \\
481 \\
129\end{array}$ & $\begin{array}{l}51.7 \\
18.4 \\
15.3 \\
6.6 \\
6.2 \\
1.7\end{array}$ & $\mathrm{P}<0.001$ \\
\hline $\begin{array}{l}\text { Chemotherapy } \\
\text { Radiation recode }\end{array}$ & $\begin{array}{l}\text { Yes } \\
\text { No/Unknown } \\
\text { Radioactive implants } \\
\text { Beam Radiation } \\
\text { Radioisotopes } \\
\text { Other } \\
\text { None/Unknown }\end{array}$ & $\begin{array}{l}139 \\
7583 \\
2468 \\
1325 \\
671 \\
205 \\
3053\end{array}$ & $\begin{array}{l}1.8 \\
98.2 \\
32 \\
17.2 \\
8.7 \\
2.7 \\
39.5\end{array}$ & $\begin{array}{l}P<0.001 \\
P=0.006\end{array}$ \\
\hline
\end{tabular}

(Continued) 
Table I (Continued).

\begin{tabular}{|c|c|c|c|c|}
\hline Variable & Value & Frequency & Percent & $p$-value \\
\hline Radiation sequence recode & $\begin{array}{l}\text { Radiation prior to surgery } \\
\text { Radiation after surgery } \\
\text { No radiation and/or cancer-directed surgery } \\
\text { Other }\end{array}$ & $\begin{array}{l}7183 \\
271 \\
215 \\
22\end{array}$ & $\begin{array}{l}93 \\
3.5 \\
2.8 \\
0.3\end{array}$ & $P=0.002$ \\
\hline Type of follow-up expected & $\begin{array}{l}\text { Active follow-up } \\
\text { Autopsy/death certificate only cases } \\
\text { SF/Oakland only (originally inactive/now active) }\end{array}$ & $\begin{array}{l}7711 \\
2 \\
9\end{array}$ & $\begin{array}{l}99.9 \\
0 \\
0.1\end{array}$ & $P=0.203$ \\
\hline
\end{tabular}

Note: Statistical significance was achieved at $p$-value $<0.05$.

certificate only cases. Chemotherapy was received by 139 patients $(1.8 \%)$ with 7583 patients $(98.2 \%)$ not receiving or not known to have received chemotherapy. 2468 (32\%) of patients received radioactive implants, 1325 (17.2\%) of patients received beam radiation, and 671 (8.7\%) of patients received radioisotopes. Radiation sequences prior to surgery were obtained by 7183 (93\%) of patients with 271 (3.5\%) receiving post-surgery radiation and $215(2.8 \%)$ of patients receiving no radiation and/or cancer-directed surgery. ICD10 behavior recodes showcased $5610(72.6 \%)$ cases with malignant melanoma NOS, $780(10.1 \%)$ cases with mixed epithelioid and spindle cell melanoma, $477(6.2 \%)$ cases with spindle cell melanoma type B, $467(6 \%)$ cases with spindle cell melanoma NOS, 261 (3.4\%) cases with epithelioid cell melanoma, $58(0.8 \%)$ cases with amelanotic melanoma, and $20(0.3 \%)$ cases with spindle cell melanoma type A. 49 cases were grouped together into "Other" due to the remarkably low prevalence and rarity, as mentioned in the methods section. Diagnostic confirmation with positive histology ( $\mathrm{N}=3993,51.7 \%$ ), radiography without microscopic confirmation $(\mathrm{N}=1423,18.4 \%)$, direct visualization without microscopic confirmation $(\mathrm{N}=1184,15.3 \%)$, positive exfoliative cytology with no positive histology $(\mathrm{N}=512$, $6.6 \%$ ), and clinical diagnosis only ( $\mathrm{N}=481,6.2 \%)$ were seen.
Table 2 shows the univariable Cox regression model results of aged groups for both cause-specific survival and other-cause survival models. Univariable results for causespecific survival show that the hazard of cause-specific death is $58.6 \%$ lower for choroidal cancer patients aged 25-49 years as compared to patients aged $75+(\mathrm{HR}=0.414, \mathrm{CI}$ $0.355-0.483, \mathrm{p}<0.001)$. The hazard of cause-specific death is $29.9 \%$ lower for choroidal cancer patients aged $50-74$ years as compared to patients aged $75+(\mathrm{HR}=0.701, \mathrm{CI}$ $0.622-0.789, \mathrm{p}<0.001)$. There is not a significant difference in the hazard of cause-specific death between choroidal cancer patients aged 0-24 years as compared to patients aged 75 + years $(\mathrm{HR}=0.685,0.469-1.001, \mathrm{p}=0.051)$.

Univariable results for other cause survival show that the hazard of other cause death is $79.0 \%$ lower for choroidal cancer patients aged 50-74 years as compared to patients aged $75+$ years $(\mathrm{HR}=0.210$, CI $0.188-0.235$, $\mathrm{p}<0.001)$. The hazard of other cause death is $97.1 \%$ lower for choroidal cancer patients aged 25-49 years as compared to patients aged $75+$ years $(\mathrm{HR}=0.029, \mathrm{CI}$ $0.023-0.038, \mathrm{p}<0.001)$. The hazard of other cause death is $99.4 \%$ lower for choroidal cancer patients aged 0-24 years as compared to patients aged $75+$ years $(\mathrm{HR}=0.006$, CI 0.001-0.043, $\mathrm{p}<0.001)$.

Table 2 Univariable Cox Regression Results

\begin{tabular}{|c|c|c|c|c|}
\hline \multirow[t]{2}{*}{ Age } & \multicolumn{2}{|c|}{ Other-Cause Survival } & \multicolumn{2}{|c|}{ Cause-Specific Survival } \\
\hline & $\mathrm{HR}^{*}(95 \% \mathrm{Cl} *)$ & p-value* & $\mathrm{HR}^{*}\left(95 \% \mathrm{Cl}^{*}\right)$ & p-value* \\
\hline $75+$ years & Ref. & Ref. & Ref. & Ref. \\
\hline 50-74 years & $0.210(0.188,0.235)$ & $<0.001$ & $0.70 \mathrm{I}(0.622,0.789)$ & $<0.001$ \\
\hline $25-49$ years & $0.029(0.023,0.038)$ & $<0.001$ & $0.414(0.355,0.483)$ & $<0.001$ \\
\hline $0-24$ years & $0.006(0.00 \mathrm{I}, 0.043)$ & $<0.001$ & $0.685(0.469,1.001)$ & 0.051 \\
\hline
\end{tabular}

Notes: *Hazards ratio, 95\% confidence interval. *Statistical significance achieved at $p<0.05$. 


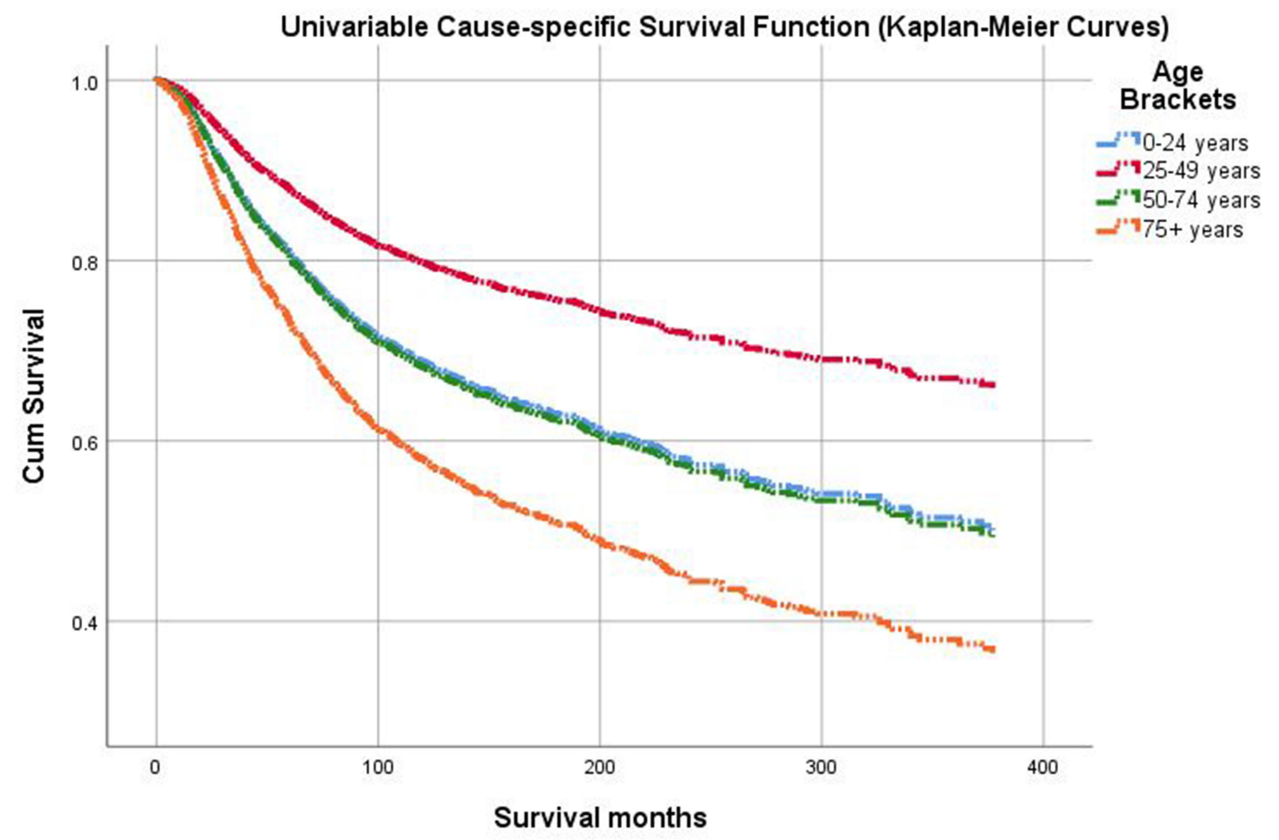

Figure I Kaplan-Meier plot shows the differences in cumulative cause-specific survival over time for choroidal cancer patients between 25 and 49 years of age. (top, red line) as compared to patients aged 75+ (bottom, orange line). The log-rank (Mantel-Cox) test showed that the cause-specific survival distributions for the different levels of aged groups at diagnosis are significantly different $(\mathrm{p}<0.00 \mathrm{I})$.

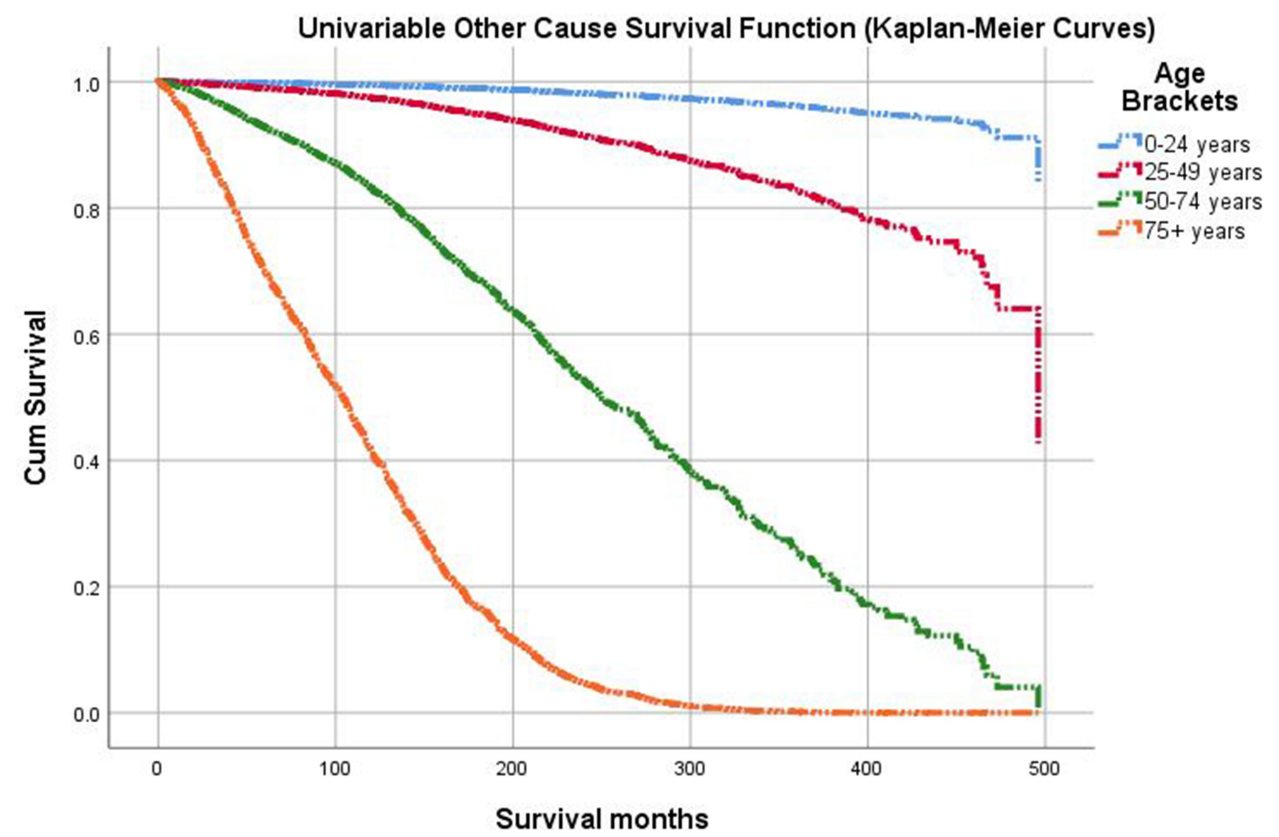

Figure 2 Kaplan-Meier plot shows the differences in cumulative other-cause survival over time for choroidal cancer patients aged 25-49 (red line) as compared to aged 75+ patients (bottom, orange line). The log-rank (Mantel-Cox) test showed that the other-cause survival distributions for the different levels of aged groups at diagnosis are significantly different $(\mathrm{p}<0.001)$.

After assessing the log-minus-log plots for the unadjusted models, time-dependent covariate modeling was utilized and determined to reveal no significance, supporting the assumption of proportional hazards (Figures 1 and 2).
Table 3 shows the multivariable Cox regression results of age for both cause-specific survival and other-cause survival models. Multivariable results for cause-specific survival show that after adjusting for confounding variables, the hazard of cause-specific death for choroidal 
Table 3 Multivariable Cox Regression Results

\begin{tabular}{|l|c|c|c|c|}
\hline \multirow{2}{*}{ Age } & \multicolumn{2}{|c|}{ Other-Cause Survival } & \multicolumn{2}{c|}{ Cause-Specific Survival } \\
\cline { 2 - 5 } & HR* $\left(\mathbf{9 5 \%} \mathbf{C l}^{*}\right)$ & p-value* & HR* $(95 \%$ CI*) & R-value* \\
\hline $0-24$ years & Ref. & Ref. & $0.694(0.469,1.027)$ & 0.068 \\
\hline $25-49$ years & $5.275(0.730,38.139)$ & 0.099 & $1.173(0.799,1.721)$ & 0.415 \\
\hline $50-74$ years & $39.066(5.459,279.590)$ & $<0.001$ & $1.718(1.155,2.555)$ & 0.008 \\
\hline $75+$ years & $178.764(24.908,1282.957)$ & $<0.001$ & & \\
\hline
\end{tabular}

Notes: *Hazards ratio, 95\% confidence interval. *Statistical significance achieved at $p<0.05$.

cancer patients is significantly $(71.8 \%)$ higher for patients aged $75+$ years compared to patients aged $0-24$ years (HR $=1.718$, CI $1.155-2.555, \mathrm{p}<0.008)$. The hazard of causespecific death for choroidal cancer patients is not significantly lower $(30.6 \%)$ for patients aged $25-49$ years as compared to patients aged $0-24$ years $(\mathrm{HR}=0.694, \mathrm{CI}$ $0.469-1.027, \mathrm{p}<0.068$ ). In addition, the hazard of causespecific death for choroidal cancer patients is not significantly $(17.3 \%)$ higher for patients aged $50-74$ years than patients aged $0-24$ years $(\mathrm{HR}=1.173, \mathrm{p}<0.415)$.

Multivariable results for other cause survival show that after adjusting for confounding variables, the hazard of other-cause death in choroidal cancer patients is not significantly higher for patients aged 25-49 years as compared to patients aged $0-24$ years $(\mathrm{HR}=5.275, \mathrm{p}<0.099)$.
There are significant increases in the hazard of other-cause death between choroidal cancer patients aged $50-74$ years and aged $0-24$ years $(\mathrm{p}<0.001)$, as well as patients aged $75+$ years and aged $0-24$ years $(\mathrm{p}<0.001)$, after adjusting for confounding variables. These results confirm outcomes from univariable analysis (Figures 3 and 4).

In adjusted cause-specific analysis, patients of SpanishHispanic-Latino origin received $25.1 \%$ decreased hazards compared to patients of Hispanic-Latino origin (HR = $0.749, \mathrm{p}<0.008)$ in patients between 0 and 24 years of age. Patients between 0 and 24 years of age who do not receive chemotherapy experience increased hazards compared to those who receive chemotherapy ( $\mathrm{HR}=3.045$, $\mathrm{p}<0.001)$. Diagnostic confirmation yielded greater hazards with positive histology and positive exfoliative

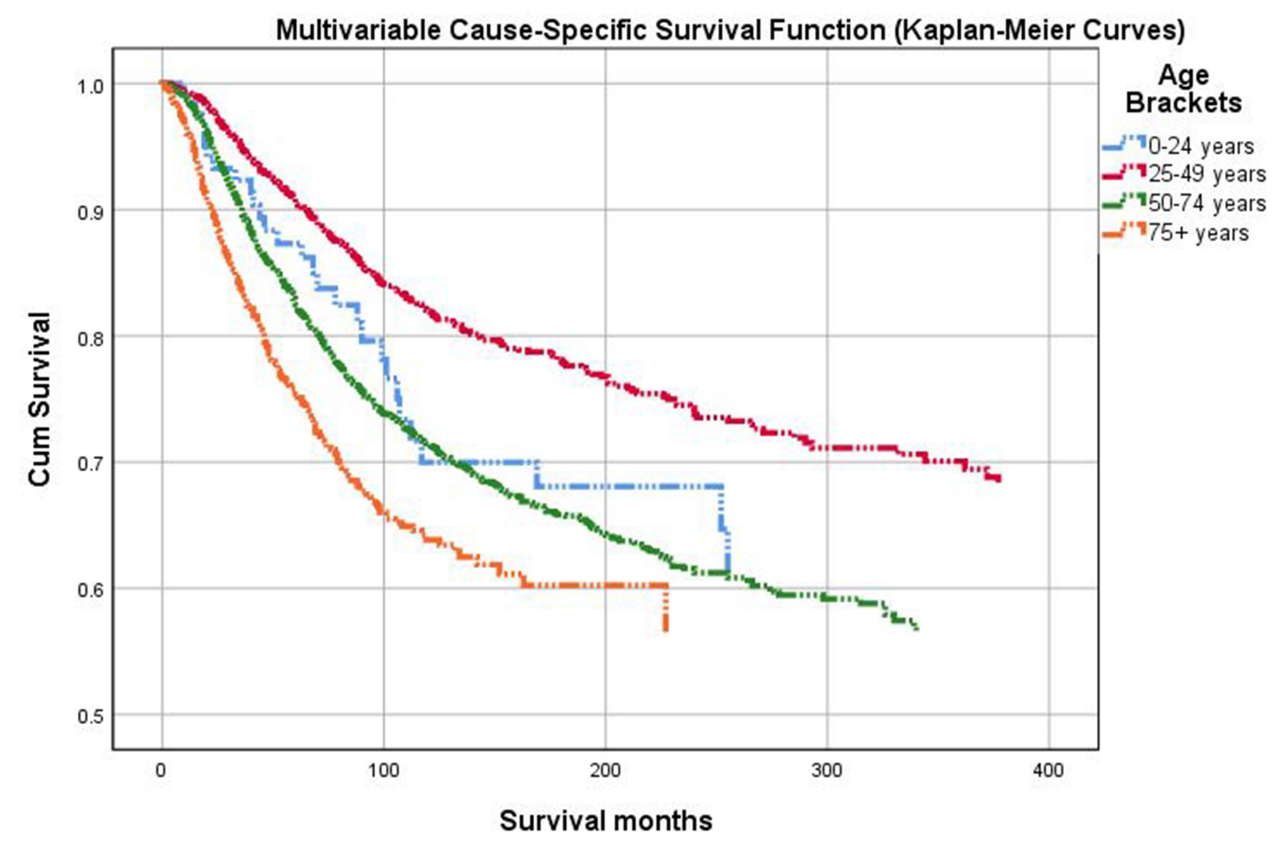

Figure 3 Kaplan-Meier plot shows the differences in cumulative cause-specific survival over time for the choroidal cancer patients aged $25-49$ years (top, red line) as compared to patients aged $75+$ years (bottom, orange line), using Cox-model based estimates after adjusting for confounding variables. 


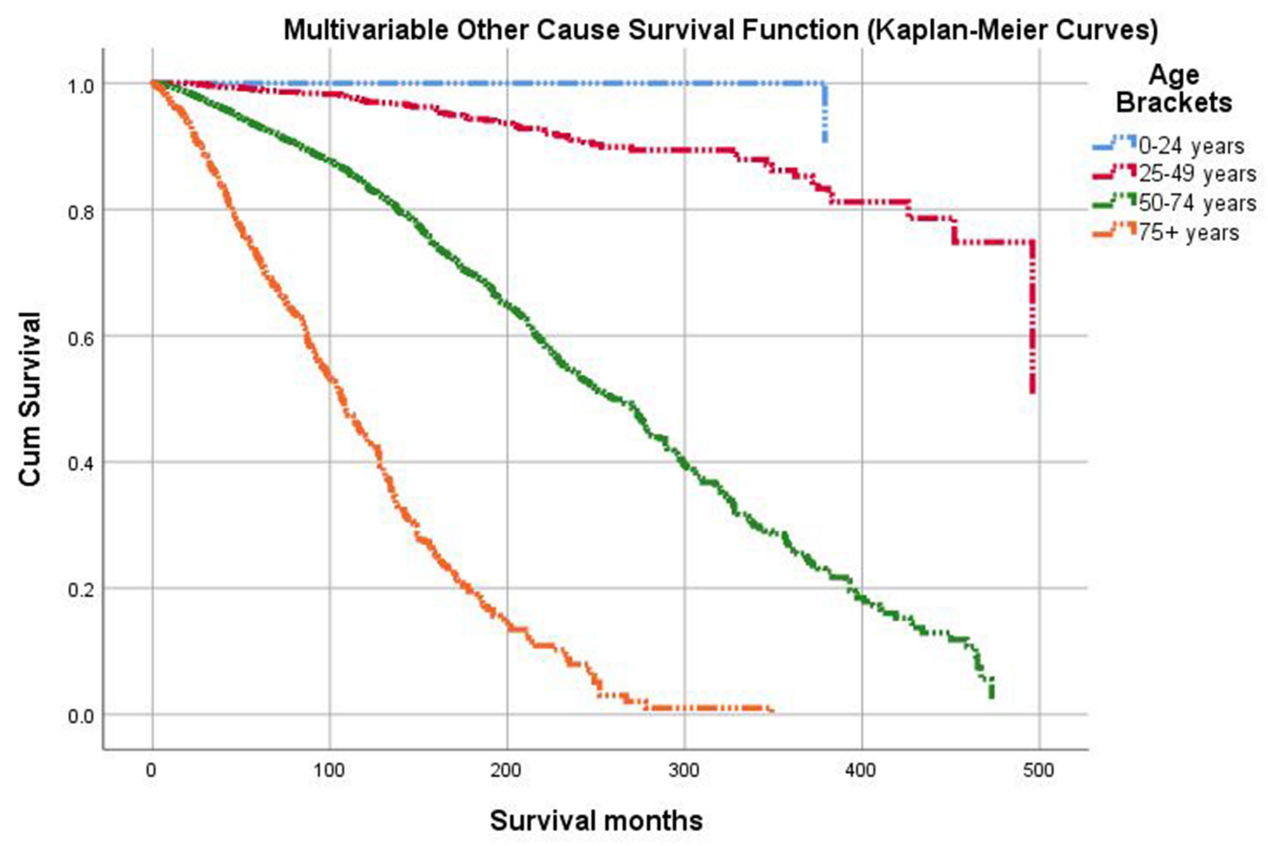

Figure 4 Kaplan-Meier plot shows the differences in cumulative other-cause survival over time for choroidal cancer patients aged $0-24$ years (top, blue line) as compared to patients aged $75+$ years (bottom, orange line), using Cox-model based estimates after adjusting for confounding variables.

cytology with no positive histology compared to patients with clinical diagnosis only $(\mathrm{HR}=2.375, \mathrm{p}<0.001 ; \mathrm{HR}=$ $1.790, p=0.001$, respectively). For patients between 50 and 74 years of age with amelanotic melanoma and mixed epithelioid and spindle cell melanoma, greater hazards was experienced compared to patients with malignant melanoma NOS in the same age group (HR $=1.162, \mathrm{p}=$ $0.029 ; \mathrm{HR}=1.580, \mathrm{p}<0.001)$. In contrast, patients between 50 and 74 years of age diagnosed with epithelioid cell melanoma, spindle cell melanoma NOS, and spindle cell melanoma type A experienced decreased hazards compared to patients with malignant melanoma NOS in the same age group $(\mathrm{HR}=0.469, \mathrm{p}<0.001 ; \mathrm{HR}=0.188$, $\mathrm{p}<0.018 ; \mathrm{HR}=0.575, \mathrm{p}<0.001)$. In addition, patients who were widowed at the time of diagnosis and between the ages of 50 and 74 experienced $20.8 \%$ decreased hazards compared to patients who were married within the same age group $(\mathrm{HR}=0.792, \mathrm{p}=0.018)$. In contrast, patients who were divorced at the time of diagnosis and between the ages of 50 and 74 experienced $22.3 \%$ increased hazards compared to married patients within the same age group $(H R=1.223, p=0.009)$. Table 4 showcases additional information regarding the influence of confounders in multivariable analysis.

Multivariable analysis demonstrated significant influences of ICD-O-3 Histology/behavior on cause-specific survival diagnosed with choroidal malignancies in patients diagnosed between the ages of 0 and 24. More specifically, a $16.2 \%$ and $58.0 \%$ increase in cause-specific mortality was showcased in patients diagnosed with 8770/3: mixed epithelioid and spindle cell melanoma $(\mathrm{HR}=1.16, \mathrm{p}=$ 0.029 ) and 8771/3: epithelioid cell melanoma of the choroid $(\mathrm{HR}=1.580, \mathrm{p}<0.001)$ compared to individuals diagnosed with 8720/3: malignant melanoma NOS of the choroid.

Various histological subtypes of choroidal cancers including 8772/3: Spindle cell melanoma NOS, 8773/3 Spindle cell melanoma type A, and 8774/3: Spindle cell melanoma type B were highlighted to significantly decrease cause-specific mortality by $53.1 \%$ (HR $=0.469, \mathrm{p}<0.001)$, $81.2 \%(\mathrm{HR}=0.188, \mathrm{p}=0.018)$, and $42.5 \%(\mathrm{HR}=0.575, \mathrm{p}<$ 0.001 ) as compared to patients diagnosed with 8720/3: malignant melanoma NOS of the choroid. Many ICD-O-3 histological subtypes did not fulfill the minimum criteria for patient case number. Therefore, these subtypes were grouped during analysis to act as a provision for enhanced statistical clarity and discrimination.

Univariable analysis of the impact of radiation on survival in patients with choroidal cancers revealed overall significance with cause-specific modeling $(\mathrm{p}<0.001)$ and radioactive implants incurring hazards 30\% lower compared to patients receiving beam radiation $(H R=0.700$, $\mathrm{p}<0.001)$. In addition, patients receiving radioisotopes have no significant change in survival compared to 
Table 4 Multi-Variable Cox Regression Results (Continued)

\begin{tabular}{|c|c|c|c|c|c|}
\hline Variable Name & Value & $\begin{array}{l}\text { Exp } \\
\text { (B) }\end{array}$ & $\begin{array}{l}\text { 95.0\% Cl for Hazard } \\
\text { Ratios }\end{array}$ & & p-value \\
\hline & & & Lower & Upper & \\
\hline Race/Ethnicity & $\begin{array}{l}\text { White } \\
\text { Non-White }\end{array}$ & $\begin{array}{l}\text { ref } \\
0.496\end{array}$ & $\begin{array}{l}\text { ref } \\
0.346\end{array}$ & $\begin{array}{l}\text { ref } \\
0.713\end{array}$ & $\begin{array}{l}<0.001 \\
<0.001\end{array}$ \\
\hline $\begin{array}{l}\text { Hispanic Origin } \\
\text { Chemotherapy } \\
\text { Laterality }\end{array}$ & $\begin{array}{l}\text { Non-Spanish-Hispanic-Latino } \\
\text { Spanish-Hispanic-Latino } \\
\text { Yes } \\
\text { Left } \\
\text { Right } \\
\text { other }\end{array}$ & $\begin{array}{l}\text { ref } \\
0.749 \\
0.328 \\
\text { ref } \\
1.033 \\
1.333\end{array}$ & $\begin{array}{l}\text { ref } \\
0.606 \\
0.252 \\
\text { ref } \\
0.944 \\
0.843\end{array}$ & $\begin{array}{l}\text { ref } \\
0.926 \\
0.427 \\
\text { ref } \\
1.131 \\
2.108\end{array}$ & $\begin{array}{l}<0.001 \\
0.008 \\
<0.001 \\
0.393 \\
0.48 \\
0.218\end{array}$ \\
\hline Grade & $\begin{array}{l}\text { Unknown } \\
\text { Undifferentiated; anaplastic; Grade IV and B-cell; pre-B; } \\
\text { B-precursor } \\
\text { Poorly differentiated; Grade III } \\
\text { Moderately differentiated; Grade II } \\
\text { Well differentiated; Grade I }\end{array}$ & $\begin{array}{l}\text { ref } \\
1.343 \\
0.574 \\
1.217 \\
1.642\end{array}$ & $\begin{array}{l}\text { ref } \\
0.668 \\
0.135 \\
0.484 \\
0.749\end{array}$ & $\begin{array}{l}\text { ref } \\
2.7 \\
2.439 \\
3.065 \\
3.602\end{array}$ & $\begin{array}{l}0.42 \\
0.407 \\
0.452 \\
0.676 \\
0.216\end{array}$ \\
\hline Marital Status & $\begin{array}{l}\text { Married } \\
\text { Widowed } \\
\text { Divorced } \\
\text { Single } \\
\text { Other/Unknown }\end{array}$ & $\begin{array}{l}\text { ref } \\
0.792 \\
1.223 \\
1.153 \\
1.075\end{array}$ & $\begin{array}{l}\text { ref } \\
0.652 \\
1.051 \\
0.969 \\
0.927\end{array}$ & $\begin{array}{l}\text { ref } \\
0.961 \\
1.423 \\
1.372 \\
1.246\end{array}$ & $\begin{array}{l}0.002 \\
0.018 \\
0.009 \\
0.108 \\
0.339\end{array}$ \\
\hline $\begin{array}{l}\text { Diagnostic } \\
\text { Confirmation }\end{array}$ & $\begin{array}{l}\text { Clinical diagnosis only } \\
\text { Radiography without microscopic confirmation } \\
\text { Positive histology } \\
\text { Positive exfoliative cytology, no positive histology } \\
\text { Direct visualization without microscopic confirmation }\end{array}$ & $\begin{array}{l}\text { ref } \\
1.41 \\
0.882 \\
2.375 \\
1.79\end{array}$ & $\begin{array}{l}\text { ref } \\
0.885 \\
0.656 \\
1.804 \\
1.276\end{array}$ & $\begin{array}{l}\text { ref } \\
2.246 \\
1.187 \\
3.125 \\
2.511\end{array}$ & $\begin{array}{l}<0.001 \\
0.148 \\
0.408 \\
<0.001 \\
0.001\end{array}$ \\
\hline Icd 10 behavior & $\begin{array}{l}\text { 8720/3: Malignant melanoma, NOS } \\
\text { 8730/3: Amelanotic melanoma } \\
\text { 8770/3: Mixed epithelioid and spindle cell melanoma } \\
\text { 8771/3: Epithelioid cell melanoma } \\
\text { 8772/3: Spindle cell melanoma, NOS } \\
\text { 8773/3: Spindle cell melanoma, type A } \\
\text { 8774/3: Spindle cell melanoma, type B } \\
\text { Other }\end{array}$ & $\begin{array}{l}\text { ref } \\
0.509 \\
1.162 \\
1.58 \\
0.469 \\
0.188 \\
0.575 \\
0.901\end{array}$ & $\begin{array}{l}\text { ref } \\
0.228 \\
1.015 \\
1.304 \\
0.375 \\
0.047 \\
0.474 \\
0.384\end{array}$ & $\begin{array}{l}\text { ref } \\
1.137 \\
1.33 \\
1.915 \\
0.586 \\
0.753 \\
0.697 \\
2.112\end{array}$ & $\begin{array}{l}<0.001 \\
0.1 \\
0.029 \\
<0.001 \\
<0.001 \\
0.018 \\
<0.001 \\
0.811\end{array}$ \\
\hline Sex & $\begin{array}{l}\text { Female } \\
\text { Male }\end{array}$ & $\begin{array}{l}\text { ref } \\
0.933\end{array}$ & $\begin{array}{l}\text { ref } \\
0.849\end{array}$ & $\begin{array}{l}\text { ref } \\
1.025\end{array}$ & $\begin{array}{l}0.25 \\
0.146\end{array}$ \\
\hline Radiation & $\begin{array}{l}\text { Beam Radiation } \\
\text { None/Unknown } \\
\text { Radioactive implants } \\
\text { Radioisotopes } \\
\text { Other }\end{array}$ & $\begin{array}{l}\text { ref } \\
1.046 \\
1.043 \\
0.81 \\
0.952\end{array}$ & $\begin{array}{l}\text { ref } \\
0.78 \\
0.786 \\
0.607 \\
0.693\end{array}$ & $\begin{array}{l}\text { ref } \\
1.402 \\
1.384 \\
1.08 \\
1.308\end{array}$ & $\begin{array}{l}0.006 \\
0.765 \\
0.771 \\
0.15 \\
0.76\end{array}$ \\
\hline
\end{tabular}

(Continued) 
Table 4 (Continued).

\begin{tabular}{|c|c|c|c|c|c|}
\hline Variable Name & Value & $\begin{array}{l}\text { Exp } \\
\text { (B) }\end{array}$ & $\begin{array}{l}\text { 95.0\% Cl for Hazard } \\
\text { Ratios }\end{array}$ & & $p$-value \\
\hline & & & Lower & Upper & \\
\hline \multirow{4}{*}{$\begin{array}{l}\text { Radiation sequence } \\
\text { recode }\end{array}$} & Radiation prior to surgery & ref & ref & ref & 0.002 \\
\hline & Radiation after surgery & 1.31 & 0.975 & 1.759 & 0.073 \\
\hline & No radiation and/or cancer-directed surgery & 0.846 & 0.669 & 1.069 & 0.161 \\
\hline & Other & 1.212 & 0.607 & 2.422 & 0.586 \\
\hline \multirow{2}{*}{$\begin{array}{l}\text { Type of follow-up } \\
\text { expected }\end{array}$} & $\mathrm{I}=\mathrm{SF} /$ Oakland only (originally inactive/now active) & ref & ref & ref & 0.251 \\
\hline & Active follow-up & 0.564 & 0.234 & 1.362 & 0.203 \\
\hline
\end{tabular}

patients receiving beam radiation $(\mathrm{HR}=0.856, \mathrm{p}=0.892)$. Figure 5 provides a visual of Kaplan-Meier curves for survival by radiation treatment group.

Univariable analysis independently assessing chemotherapy on survival in patients with choroidal cancers showcased $62.8 \%$ decreased hazards compared to patients who either did not receive chemotherapy or had an unknown status $(\mathrm{HR}=0.377, \mathrm{p}<0.001)$.

\section{Discussion}

\section{Age}

The association between advancing age and mortality in patients diagnosed with ocular cancers is inherently complex and multi-faceted. ${ }^{14}$ Progressive age allows additional time for increased propensities of metastatic spread, direct extension into the ciliary body, tumor growth, and all-cause mortality. ${ }^{14,15}$ In addition, a later age at diagnosis likely indicates delayed therapeutic implementation. ${ }^{4}$ Chromosomal aberrations contribute to underlying genetic predispositions to malignant behaviors and tend to manifest at later ages when decreased efficacy of cellular repair and genomic stability take greater precedence. ${ }^{16,17}$

This study determined the correlation of advanced age with treatment and intraocular spread; however, no strong association was demonstrated between age at death and relevant survival predictors. ${ }^{4}$ Studies describing the

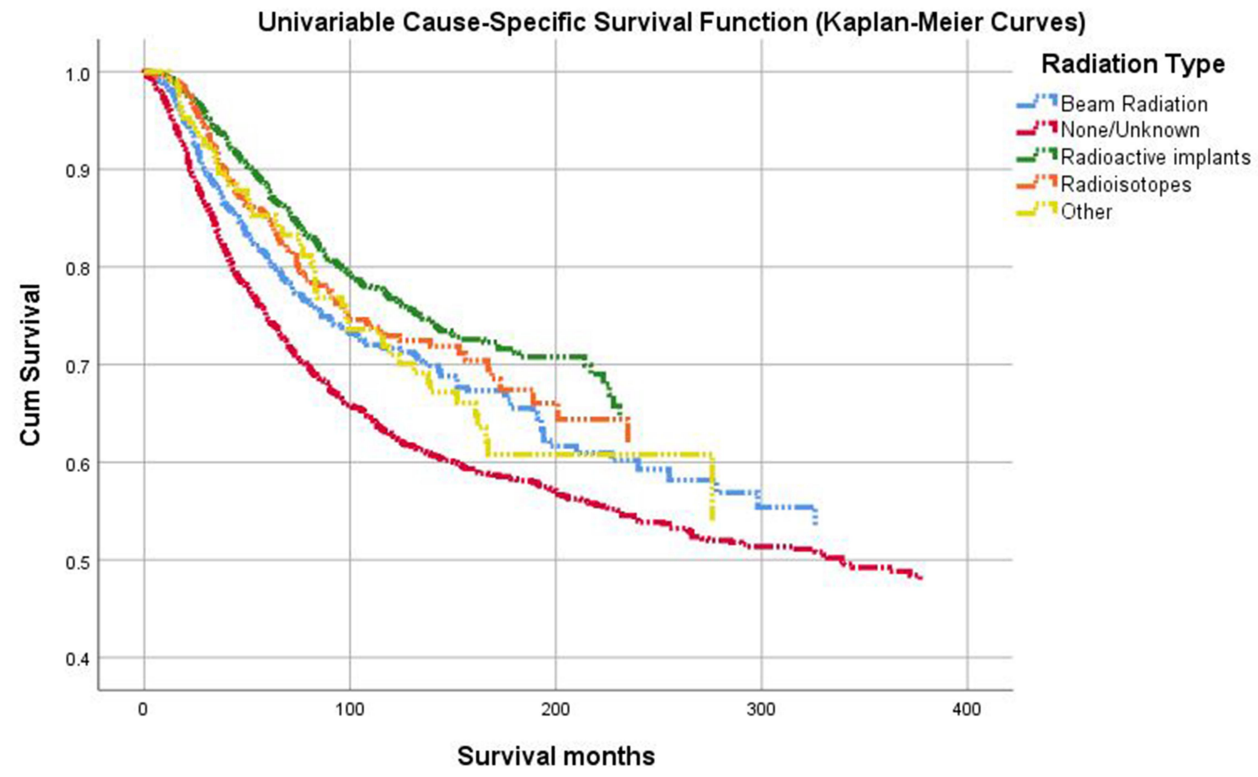

Figure 5 Kaplan-Meier plot shows the differences in cumulative univariable cause-specific survival over time for choroidal cancer patients treated with radioactive implants (top, green line) as compared to patients treated with no or unknown treatments (bottom, red line) using Cox-model based estimates. The log-rank (Mantel-Cox) test showed that the cause-specific survival distributions for the different radiation treatment groups are significantly different $(\mathrm{p}<0.00 \mathrm{l})$. 
significance of mortality rates with age are few to none; however, this study noted an increase in ophthalmic nonHodgkin lymphoma (NHL) rates with age as compared to non-ophthalmic extranodal NHL, irrespective of race. ${ }^{18}$ This 2014 publication in JAMA Ophthalmology explicitly justified repeated survival studies in patients with choroidal melanomas due to historically low sample sizes with subsequent compromise of statistical validation. ${ }^{4}$

Our study either echoes similar findings or provides expiation for limitations in a multitude of studies describing the influence of age on survival amongst the collectivity of known choroidal cancers with a relatively large sample of 7722 patients. Relevant findings related to age in this study include significantly increased hazard of cause-specific and other cause mortality with advancing age in adjusted and unadjusted models.

\section{Therapy}

In the setting of choroidal malignancies, therapeutic implementation can involve the use of external beam radiotherapy, ${ }^{19}$ brachytherapy, ${ }^{19}$ gamma knife radiosurgery, ${ }^{20}$ proton beam radiotherapy, ${ }^{21}$ plaque radiotherapy, ${ }^{22}$ transpupillary thermotherapy, ${ }^{23}$ photodynamic therapy, ${ }^{24}$ intravitreal anti-vascular endothelial growth factor injection, ${ }^{25}$ systemic chemotherapy, ${ }^{26}$ immunotherapy, ${ }^{26}$ and/or hormone therapy. ${ }^{27}$ The strategic employment of these modalities depends on various factors including histological subtype, laterality, number of choroidal tumors, systemic status, and characterization of metastatic propensity. Enucleation can be utilized for patients with advanced disease, blindness, and/or orbital pain. ${ }^{4}$ A study highlights a lack of statistical influence on cause-specific and overall survival between brachytherapy and external beam radiotherapy in patients diagnosed with choroidal melanomas. ${ }^{19}$ On the contrary, our univariable analysis concerning the totality of choroidal cancers showcases significantly decreased cause-specific mortality (HR $=0.700, \mathrm{p}<0.001)$ in patients receiving radioactive implants as compared to patients receiving beam radiation, as seen via Kaplan-Meier curves in Figure 5. Despite these findings, beam radiotherapy allows for concentrated irradiation, reduced scattering, and supporting evidence of treatment efficacy via tumor regression of choroidal metastases. $^{21,28}$ Bilateral, multifocal choroidal metastases with concurrent presentation of poor systemic status are preferably managed with systemic chemotherapy, immunotherapy, and/or hormonal therapy. ${ }^{27}$ Tumor recession was observed in $58.82 \%$ of patients with metastatic breast cancer to the choroid via aromatase therapy. ${ }^{27}$ Indeed, our findings mirror these outcomes with chemotherapy significantly influencing survival via a hazard reduction of $62.3 \%(\mathrm{HR}=0.377, \mathrm{p}<0.001)$.

\section{Histological Subtype}

The authors believe this study provides insight into the controversial nature of the influence of age on survival in patients with uveal melanomas. ${ }^{9-12}$ The SEER database allows for significant stratification of choroidal cancers as a class into the variety of histological subtypes. ${ }^{13}$ In particular, our study highlights differential influences of histological subtypes on survival specifically within the constituencies of choroidal melanomas. For example, while spindle cell melanoma type A significantly reduces adjusted cause-specific hazards by $81.2 \%$ as compared to patients with malignant melanoma, a diagnosis of epithelioid cell melanoma increases hazards by $58 \%$ as compared to patients with malignant melanoma in patients diagnosed between 50 and 74 years of age. Based on these results, it is clear that specific histological subtypes within the class of choroidal melanomas can significantly impact survival in opposing directions. Further research is required to assess the totality of uveal (choroid, iris, and ciliary body in tandem) melanomas in their survival by age with stratification by histological subtypes.

Interestingly, pathognomonic features of balloon cell melanoma of the choroid histology have been identified in roughly $10 \%$ of malignant melanoma of the choroid and ciliary bodies, indicating a significant overlap in histological examination. ${ }^{29}$ Epidemiological analysis of uveal melanomas shows that while the median age at diagnosis for spindle cell tumors was significantly less than epithelioid and mixed tumors, spindle cell tumors demonstrated significantly greater cause-specific survival $(\mathrm{p}<0.0001){ }^{30}$ These findings parallel our results as spindle cell tumors (NOS, type A, type B) significantly decrease adjusted cause-specific hazards as compared to individuals diagnosed with malignant melanoma in patients between the ages of 0 and $24(\mathrm{HR}=0.469, \mathrm{p}<0.001 ; \mathrm{HR}=0.188, \mathrm{p}=$ $0.018 ; \mathrm{HR}=0.575, \mathrm{p}<0.001$, respectively). Also, our findings corroborate enhanced lethality of mixed epithelioid and spindle cell melanoma $(\mathrm{HR}=1.160, \mathrm{p}=0.029)$ and epithelioid cell melanoma of the choroid $(\mathrm{HR}=1.580$, $\mathrm{p}<0.001)$.

While hemangiosarcoma of the choroid is partially characterized in dogs and horses, case reports in humans remain a largely uncharacterized territory. ${ }^{31}$ Due to the 
rarity of certain choroidal cancers such as choroidal nonHodgkin lymphoma (NHL) $)^{32-36}$ and choroidal diffuse large B-cell lymphoma (DLBCL), ${ }^{37}$ statistical evidence with clear objectivity cannot be provided. When these rare cancers with limited sample sizes were grouped together in our analysis, the statistical significance of influence on cause-specific mortality was not achieved $(\mathrm{HR}=0.933, \mathrm{p}=0.811)$. These results are also corroborated by an observation case series $(\mathrm{N}=59)$ of patients diagnosed with choroidal lymphomas in lack of influence of survival by age. ${ }^{7}$

The outcomes of this survival analysis are strengthened by a relatively large sample size $(\mathrm{N}=7722)$ and clear extraction of clinical trajectories with survival endpoints by virtue of the SEER Program. Conversely, stratification of this cohort by age, grade, and receipt of chemotherapy revealed substantial differences in sample size. While these are inherent characteristics of the database and disease process under question, differential sample sizes during analysis do not create optimal circumstances for true statistical discrimination of survival. Of note, nuanced limitations to the SEER database involve sensitivity of treatment data. Patients who receive cancer diagnosis within public hospital systems are reported within the SEER database. However, if the patient decides to seek the care of cancer with privatecare physicians, then treatment data remain listed as unknown. For these reasons, while the specificity of treatment data within the SEER software is appreciable, sensitivity is not.

\section{Conclusion}

Age, treatment modality, and ICD-O-3 histology/behavior significantly influence cause-specific and other cause mortality in patients diagnosed with choroidal cancers. Unique patterns of influence on survival are revealed when assessing the collectivity of these malignancies irrespective of subtype. Clinicians should continue to implement real-time standard risk management in patients diagnosed with choroidal malignancies with age and strategic therapy in mind.

\section{Acknowledgment}

Jawad Khan and Shaheer Ali should be considered joint second authors.

\section{Disclosure}

The authors report no conflicts of interest in this work.

\section{References}

1. Zloto O, Pe'er J, Frenkel S. Gender differences in clinical presentation and prognosis of uveal melanoma. Invest Ophthalmol Vis Sci. 2013;54(1):652-656. doi:10.1167/iovs.12-10365

2. Urs R, Ketterling JA, Yu ACH, Lloyd HO, Yiu BYS, Silverman RH. Ultrasound imaging and measurement of choroidal blood flow. Transl Vis Sci Technol. 2018;7(5):5. doi:10.1167/tvst.7.5.5

3. Singh N, Kulkarni P, Aggarwal AN, et al. Choroidal metastasis as a presenting manifestation of lung cancer: a report of 3 cases and systematic review of the literature. Medicine. 2012;91(4):179-194. doi:10.1097/MD.0b013e3182574a0b

4. Shields C, Arepalli S, Kaliki S. Choroidal metastases: origin, features, and therapy. Indian $J$ Ophthalmol. 2015;63(2):122-127. doi:10.4103/0301-4738.154380

5. Damato BE, Heimann H, Kalirai H, Coupland SE. Age, survival predictors, and metastatic death in patients with choroidal melanoma: tentative evidence of a therapeutic effect on survival. JAMA Ophthalmol. 2014;132 (5):605-613. doi:10.1001/jamaophthalmol.2014.77

6. Singh P, Singh A. Choroidal melanoma. Oman J Ophthalmol. 2012;5 (1):3-9. doi:10.4103/0974-620X.94718

7. Mashayekhi A, Shukla SY, Shields JA, Shields CL. Choroidal lymphoma: clinical features and association with systemic lymphoma. Ophthalmology. 2014;121(1):342-351. doi:10.1016/j. ophtha.2013.06.046

8. Kaliki S, Shields CL, Shields JA. Uveal melanoma: estimating prognosis. Indian J Ophthalmol. 2015;63(2):93-102. doi:10.4103/ 0301-4738.154367

9. Shields CL, Kaliki S, Arepalli S, et al. Uveal melanoma in children and teenagers. Saudi J Ophthalmol. 2013;27(3):197-201. doi:10.1016/j.sjopt.2013.06.013

10. Shammas HF, Blodi FC. Prognostic Factors in Choroidal and Ciliary Body Melanomas. Arch Ophthalmol. 1977;95(1):63-69. doi:10.1001/ archopht.1977.0445001006500

11. Barr CC, McLean IW, Zimmerman LE. Uveal melanoma in children and adolescents. Arch Ophthalmol. 1981;99(12):2133-2136. doi:10.1001/archopht.1981.03930021009003

12. Pogrzebielski A, Orlowska-Heitzman J, Romanowska-Dixon B. Uveal melanoma in young patients. Graefes Arch Clin Exp Ophthalmol. 2006;244(12):1646-1649. doi:10.1007/s00417-006-0347-x

13. Surveillance, Epidemiology, and End Results (SEER) Program. SEER*Stat Database: incidence - SEER 18 Regs Custom Data (with additional treatment fields), Nov 2018 Sub (1975-2016 varying) - Linked To County Attributes - Total U.S., 1969-2016 Counties, National Cancer Institute, DCCPS, Surveillance Research Program, based on the November 2018 submission. Available from: www.seer.cancer.gov. Accessed November 16, 2020.

14. Stalhammar G. Forty-year prognosis after plaque brachytherapy of uveal melanoma. Sci Rep. 2020;10(1):11297. doi:10.1038/s41598-020-68232-7

15. Damato B, Eleuteri A, Hussain R, et al. Parsimonious models for predicting mortality from choroidal melanoma. Invest Ophthalmol Vis Sci. 2020;61(4):35. doi:10.1167/iovs.61.4.35

16. Damato B, Dopierala JA, Coupland SE. Genotypic profiling of 452 choroidal melanomas with multiplex ligation-dependent probe amplification. Clin Cancer Res. 2010;16(24):6083-6092. doi:10.1158/1078-0432.CCR-10-2076

17. Negrini S, Gorgoulis VG, Halazonetis TD. Genomic instability-an evolving hallmark of cancer. Nat Rev Mol Cell Biol. 2010;11 (3):220-228. doi: $10.1038 / \mathrm{nrm} 2858$

18. Moslehi R, Schymura MJ, Nayak S, Coles FB. Ocular adnexal nonHodgkin's lymphoma: a review of epidemiology and risk factors. Expert Rev Ophthalmol. 2011;6(2):181-193. doi:10.1586/eop.11.15

19. Abrams MJ, Gagne NL, Melhus CS, Mignano JE. Brachytherapy vs. external beam radiotherapy for choroidal melanoma: survival and patterns-of-care analyses. Brachytherapy. 2016;15(2):216-223. doi:10.1016/j.brachy.2015.12.001 
20. Arnett ALH, Reynolds MM, Pulido JS, Parney IF, Laack NN. Gamma knife stereotactic radiosurgery for the treatment of primary and metastatic ocular malignancies. Stereotact Funct Neurosurg. 2017;95(6):363-368. doi:10.1159/000478271

21. Tsina EK, Lane AM, Zacks DN, Munzenrider JE, Collier JM, Gragoudas ES. Treatment of metastatic tumors of the choroid with proton beam irradiation. Ophthalmology. 2005;112(2):337-343. doi:10.1016/j.ophtha.2004.09.013

22. Hegde JV, McCannel TA, McCannel CA, et al. Juxtapapillary and circumpapillary choroidal melanoma: globe-sparing treatment outcomes with iodine-125 notched plaque brachytherapy. Graefes Arch Clin Exp Ophthalmol. 2017;255(9):1843-1850. doi:10.1007/s00417017-3703-0

23. Shields CL, Shields JA. Transpupillary thermotherapy for choroidal melanoma. Curr Opin Ophthalmol. 1999;10(3):197-203. doi:10.1097/00055735-199906000-00008

24. Harbour JW. Photodynamic therapy for choroidal metastasis from carcinoid tumor. Am J Ophthalmol. 2004;137(6):1143-1145. doi:10.1016/j.ajo.2004.01.009

25. Detorakis ET, Agorogiannis G, Drakonaki EE, Tsilimbaris MK, Pallikaris IG. Successful management of choroidal metastasis with intravitreal ranibizumab injections. Ophthalmic Surg Lasers Imaging. 2012;43:e47-e51. doi:10.3928/15428877-20120517-03

26. George B, Wirostko WJ, Connor TB, Choong NW. Complete and durable response of choroid metastasis from non-small cell lung cancer with systemic bevacizumab and chemotherapy. J Thorac Oncol. 2009;4(5):661-662. doi:10.1097/JTO.0b013e31819c9a73

27. Manquez ME, Brown MM, Shields CL, Shields JA. Management of choroidal metastases from breast carcinomas using aromatase inhibitors. Curr Opin Ophthalmol. 2006;17(3):251-256. doi:10.1097/01.icu.0000193105.22960.f6

28. Rudoler SB, Corn BW, Shields CL, et al. External beam irradiation for choroid metastases: identification of factors predisposing to long-term sequelae. Int $J$ Radiat Oncol Biol Phys. 1997;38 (2):251-256. doi:10.1016/s0360-3016(97)00050-3
29. Riley FC. Balloon cell melanoma of the choroid. Arch Ophthalmol. 1974;92(2):131-133. doi:10.1001/archopht.1974.01010010137011

30. Andreoli MT, Mieler WF, Leiderman YI. Epidemiological trends in uveal melanoma. $\mathrm{Br} J$ Ophthalmol. 2015;99(11):1550-1553. doi:10.1136/bjophthalmol-2015-306810

31. Gabor LJ, Vanderstichel RV. Primary cerebral hemangiosarcoma in a 6-week-old dog. Vet Pathol. 2006;43(5):782-784. doi:10.1354/vp.43$5-782$

32. Ramulu P, Iliff NT, Green WR, Kuo IC. Asymptomatic conjunctival mucosa-associated lymphoid tissue-type lymphoma with presumed intraocular involvement. Cornea. 2007;26(4):484-486. doi:10.1097/ ICO.0b013e3180307667

33. Lee HB, Pulido JS, Buettner H, Salomao D, Zent CS, Link TP. Intravascular B-cell lymphoma (angiotropic lymphoma) with choroidal involvement. Arch Ophthalmol. 2006;124(9):1357-1359. doi:10.1001/archopht.124.9.1357

34. Tavallali A, Shields CL, Bianciotto C, Shields JA. Choroidal lymphoma masquerading as anterior ischemic optic neuropathy. Eur $J$ Ophthalmol. 2010;20(5):959-962. doi:10.1177/11206721100 2000525

35. Mudhar HS, Sethuraman C, Khan MD, Jan SU. Intracular, pan-uveal intravascular large B-cell lymphoma associated with choroidal infarction and choroidal tri-lineage extramedullary haemtopoiesis. Histopathology. 2007;51(2):275-279. doi:10.1111/j.1365-2559.20 07.02750.x

36. Apte RS, Al-Abdulla NA, Green WR, et al. Systemic non-Hodgkin B-cell lymphoma encountered as a vanishing choroidal mass. Arch Ophthalmol. 2005;123(1):105-109. doi:10.1001/archopht.123.1.105

37. Chi M, Bucher N, Gabrielian A, MacCumber MW, Zdunek T. Subcutaneous diffuse large B-cell lymphoma with intraocular involvement. Future Oncol. 2012;8(6):757-760. doi:10.2217/ fon. 12.40
Clinical Ophthalmology

\section{Publish your work in this journal}

Clinical Ophthalmology is an international, peer-reviewed journal covering all subspecialties within ophthalmology. Key topics include: Optometry; Visual science; Pharmacology and drug therapy in eye diseases; Basic Sciences; Primary and Secondary eye care; Patient Safety and Quality of Care Improvements. This journal is indexed on PubMed

\section{Dovepress}

Central and CAS, and is the official journal of The Society of Clinical Ophthalmology (SCO). The manuscript management system is completely online and includes a very quick and fair peer-review system, which is all easy to use. Visit http://www.dovepress.com/ testimonials.php to read real quotes from published authors. 